\title{
Natural weathering studies of oil palm trunk lumber (OPTL) green polymer composites enhanced with oil palm shell (OPS) nanoparticles
}

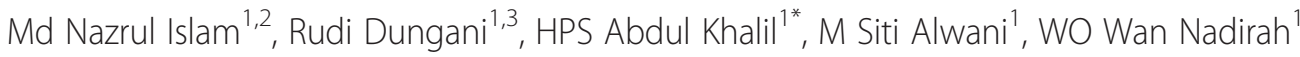 \\ and $\mathrm{H}_{\text {Mohammad Fizree }}{ }^{1}$
}

\begin{abstract}
In this study, a green composite was produced from Oil Palm Trunk Lumber (OPTL) by impregnating oil palm shell (OPS) nanoparticles with formaldehyde resin. The changes of physical, mechanical and morphological properties of the OPS nanoparticles impregnated OPTL as a result of natural weathering was investigated. The OPS fibres were ground with a ball-mill for producing nanoparticles before being mixed with the phenol formaldehyde (PF) resin at a concentration of 1, 3, 5 and 10\% w/w basis and impregnated into the OPTL by vacuum-pressure method. The treated OPTL samples were exposed to natural weathering for the period of 6 and 12 months in West Java, Indonesia according to ASTM D1435-99 standard. Physical and mechanical tests were done for analyzing the changes in phenol formaldehyde-nanoparticles impregnated (PF-NPI) OPTL. FT-IR and SEM studies were done to analyze the morphological changes. The results showed that both exposure time of weathering and concentration of PF-NPI had significant impact on physical and mechanical properties of OPTL. The longer exposure of samples to weathering condition reduced the wave numbers during FT-IR test. However, all these physical, mechanical and morphological changes were significant when compared with the untreated samples or only PF impregnated samples. Thus, it can be concluded that PF-NP impregnation into OPTL improved the resistance against natural weathering and would pave the ground for improved products from OPTL for outdoor conditions.
\end{abstract}

Keywords: Impregnation; IR-spectra; SEM; Wave number; Weight loss; Phenol formaldehyde

\section{Introduction}

Recently, plenty of oil palm trunk (OPT) and oil palm shell (OPS) as a lignocellulosic material is producing due to the increase of oil palm tree plantation (Lua and Guo 2001). This huge amount of lignocellulosic material is mostly considered as an agricultural waste. The shortage of timber supply in wood-based industries and the negative impact of the huge agricultural waste has drawn the attention of researchers to work on OPT (Abdul Khalil et al. 2010a) and OPS (Dagwa et al. 2012). However, the utilization of OPT and OPS has still not optimally done and has lower economic value. Numerous researches and development efforts have been undertaken to utilize the oil palm biomass like OPS for active charcoal

\footnotetext{
*Correspondence: akhalilhps@gmail.com

${ }^{1}$ School of Industrial Technology, Universiti Sains Malaysia, 11800 Penang, Malaysia

Full list of author information is available at the end of the article
}

(Arami-Niya et al. 2010), OPT for furniture (Abdul Khalil et al. 2012), and empty fruit bunches for pulping (Astimar et al. 2002).

The effort that led the use of OPT for zero waste; it is necessary to find out alternative measures that ensure the use of OPT inside buildings, lightweight construction materials and furniture. Impregnation of chemicals into OPT and its modification might be a way to do this. Thermosetting resin impregnation into wood was started in 1936 (Stamm and Seborg 1939) and continued until early twentieth century (Ryu et al. 1991). Impregnation of resin into non-wood specially into OPT has started in the recent years (Abdul Khalil et al. 2012; Bhat et al. 2010a). However, the synthetic resins and OPT experience photo-degradation upon exposure to water and sunlight, especially ultraviolet (UV) (Geburtig and Wachtendorf 2010). The photo-degradation of polymers originates from excited polymer-oxygen complexes, 
which are mainly produced by introducing catalyst residues, hydroperoxide groups, carbonyl groups, and double bonds during polymer manufacturing (Zou et al. 2008). It has been shown that lignin is the constituent of wood that is most likely to undergo photo-degradation, which leads to the radical induced depolymerization of lignin, hemicelluloses, and cellulose at wood surfaces (Ndiaye et al. 2008). Therefore, color fading, chalking, surface roughening, cracking, damage the wood microstructure and strength weakening of materials may caused by weathering, restricting treated OPTL to specific outdoor applications (Feist 1990). Evans et al. (1996) reported that depolymerization of lignin and cellulose caused by photo-oxidation and furthermore, degraded by physical and biological factors, and water. However, it has been reported that UV light cannot penetrate deeper than $75 \mu \mathrm{m}$ though degradation occurs deeper than this in combination with other factors (Hon 2001). Therefore, the material climate determined by wood moisture content and temperature, and their dynamics (Gobakken and Lebow 2010).

The degradation mechanisms are very complex and are influenced by many factors, e.g., rain, solar radiation and temperature, and thus, difficult to improve the weather resistance properties of wood. However, modification of wood might improve the weather resistance of wood by reducing the oxidation reactions. Different chemical modification methods have been practiced to improve the weathering resistance of wood by blocking the hydroxyl groups of cell wall polymers (Macleod et al. 1995). It was found that impregnation of methyl methacrylate monomer followed by polymerization reduce the weathering effects (Feist 1990). It was also reported that the impregnation of nanoparticles into lumber improves the weathering resistance (Lei et al. 2010).

However, all these works were done with inorganic nanoparticles. Accordingly, it may be possible to improve the weather resistance by impregnation of organic nanoparticles into wood. To the best of our knowledge, no prior report has been made on the weathering resistance properties of organic nanoparticles impregnated lumber. Thus, the aim of this study is to demonstrate the effects of OPS nanoparticles impregnation with PF resin on the natural weathering properties of OPTL. Physical, mechanical, and morphological properties of OPS nanoparticles impregnated green OPTL polymer composites would be analyzed to find out the effects.

\section{Materials and methods Material preparation}

Oil Palm Trunks (OPT) were collected from a local plantation of 30 years old from Western Indonesia. OPTs were sawn to produce samples having the dimension of $50 \times 50 \times 500 \mathrm{~mm}$ (radial, tangential and longitudinal, respectively). Only the inner part of the OPT having the density of $0.29 \mathrm{~g} \mathrm{~cm}^{-3}$ were used in the study. At least 180 samples were prepared for one experiment. The samples were kiln dried until the moisture content reached to $14 \%$ before impregnation.

Oil palm shells (OPS) were collected from a palm-oil processing mill in Banten, Indonesia in the form of chips. Nano sized particles were prepared from this OPS chips by high energy ball milling (Pulverisette, Fritsch, Germany) process for 30 hours with 170 rev $\mathrm{min}^{-1}$ rotation speed of the planet carrier.

Phenol formaldehyde (PF) resin was used to impregnate OPS nanoparticles into OPTL. The commercial grade PF resin was collected from the Palmolite Adhesive Company, Indonesia. The properties of the PF resin are shown in Table 1.

\section{Impregnation with OPS nanoparticles}

$\mathrm{PF}$ resin was prepared at high molecular weight with a concentration of $15 \% \mathrm{w} / \mathrm{w}$. Exactly 1, 3, 5 and 10\% w/w OPS nanoparticles having the size of 50 to $100 \mathrm{~nm}$ was added to that PF resin for getting different concentrations of PF-NPI. The mixtures (PF resin and OPS nanoparticles) were compounded using twin screw extruder (Haake Model Rheodrive 500). The mixture was perfectly incorporated into the chamber to begin the process of impregnation. The PF-NPI was impregnated into OPTL by vacuum-pressure method. An initial vacuum was created for 15 minutes at 3 bar followed by pressure at 7 bar for 60 minutes, and then a final vacuum was created at 3 bar for 10 minutes. Untreated samples (without nano particle impregnation) were used as control.

\section{Natural weathering test}

The natural weathering test was done according to the ASTM D1435-99 standard. The samples, after impregnation of OPS nanoparticles with resin, were exposed to natural weathering for a period of 6 and 12 months from June 2012 to May 2013 at Bogor, West Java, Indonesia. Annual average temperature, relative humidity, UV intensity, rainfall and long radiation were $25.9^{\circ} \mathrm{C}, 81.7 \%$, $856.5 \mathrm{cal} \mathrm{m}^{-2}, 1,570 \mathrm{~mm}$, and $67.2 \%$, respectively in the experimental area. The area is situated $325 \mathrm{~m}$ above the mean sea level, and the experimental place was on

Table 1 Properties of PF resin

\begin{tabular}{lc}
\hline Resin properties & Value \\
\hline Viscosity @ $25^{\circ} \mathrm{C}$ (poise) & 2.27 \\
Specific Gravity @ $25^{\circ} \mathrm{C}$ & 1.200 \\
Resin Content @ $135^{\circ} \mathrm{C}(\%)$ & 42.5 \\
$\mathrm{pH}$ (meter $/ 25^{\circ} \mathrm{C}$ ) & 12.45 \\
Molecular weight & 4000 \\
\hline
\end{tabular}


the roof of a $15 \mathrm{~m}$ high building having no shadow from a neighboring obstruction. Samples were placed vertically on the roof and exposed to the various weathering factors, such as precipitation, sunlight, temperature, moisture and wind.

\section{Testing of the materials}

The OPS nano particles were analyzed by Scanning Electron Microscope (SEM) model ZEISS (type EVO 50, Germany), Transmission Electron Microscope (TEM) with a Philips CM12 instrument, and Fourier Transform Infrared (FT-IR) model Nicolet Avatar 360 (USA) for their structure, size and functional groups, respectively. Weight loss (\%) of the treated samples was calculated according to ASTM D 3345-74 standard.

The physical properties, i.e. water absorption (WA), volumetric swelling coefficient (S), anti-swelling efficiency (ASE) and density, were measured according to BS EN 317: 1993, BS EN 317: 1993, and BS EN 325: 1993, respectively. Tensile properties, i.e. tensile strength (TS), tensile modulus (TM), and elongation at break (EB), and flexural properties, i.e. flexural strength (FS) and flexural modulus (FM) were measured by using a Instron (Model 5582, UK) Universal Testing Machine according to ASTM D 638 and ASTM D 790 standard, respectively. Impact strength (IS) was measured according to ASTM D256-04 standard by using a Ray Ran Universal Impact Pendulum (CS-1370). There were at least five replications for each type of test.

\section{Data analysis}

Univariate Analyses of variance (ANOVA) were done with linear models in a completely randomized design (CRD) by using SPSS version 16.0.

\section{Results and discussion}

Characterization of nano structured materials from OPS

The microscopic investigation confirmed that the OPS particles transformed into nano-size particles. A TEM micrograph shows that the particle size ranges from 50 to $100 \mathrm{~nm}$ (Figure 1) with an average particle size close to $50.75 \mathrm{~nm}$. The variation in particle size was developed during ball milling process. SEM micrograph revealed angular and irregular shape of OPS nanoparticles with crushing end (Figure 2). Paul et al. (2007) reported similar angular and irregular features for nano-structured materials derived from fly ash, though the fresh fly ash was mostly spherical in shape. They reported that the size reduction and all these irregularities in size and shape were evolved during high-energy ball milling.

Figure 3 shows the FT-IR spectra of OPS nanoparticles. The $\mathrm{OH}$ stretch is usually broad and a strong absorption at $3404 \mathrm{~cm}^{-1}$ corresponds to the hydroxyl group (Afrouzi et al. 2013). The stretch at $2930 \mathrm{~cm}^{-1}$ is also strong and corresponds to $-\mathrm{CH}_{2}^{-}$bonds (Firoozian et al. 2011). In addition, the frequencies at around $1732 \mathrm{~cm}^{-1}$ and $1606 \mathrm{~cm}^{-1}$ corresponds to carbonyl $(\mathrm{C}=\mathrm{O})$ groups of hemicellulose (Colom et al. 2003), and the $\mathrm{C}-\mathrm{O}$ and $\mathrm{C}=\mathrm{C}$ bonds (Dagwa et al. 2012). The absorbance peak located at $1251 \mathrm{~cm}^{-1}, 1046 \mathrm{~cm}^{-1}$ and $607 \mathrm{~cm}^{-1}$ are $\mathrm{C}-\mathrm{O}$ stretching vibration in ethers (Wetzel et al. 1998), C-OH bonding (Robert et al. 2005), and stretching and bending of poly hydroxyl groups (Klinkaewnarong and Maensiri 2010), respectively.

\section{Change of weight due to natural weathering}

Table 2 summarizes the average weight loss (\%) and weight loss prevention ratio (\%) of PF-NPI after 6 and 12 months of exposure. The PF-NP impregnation

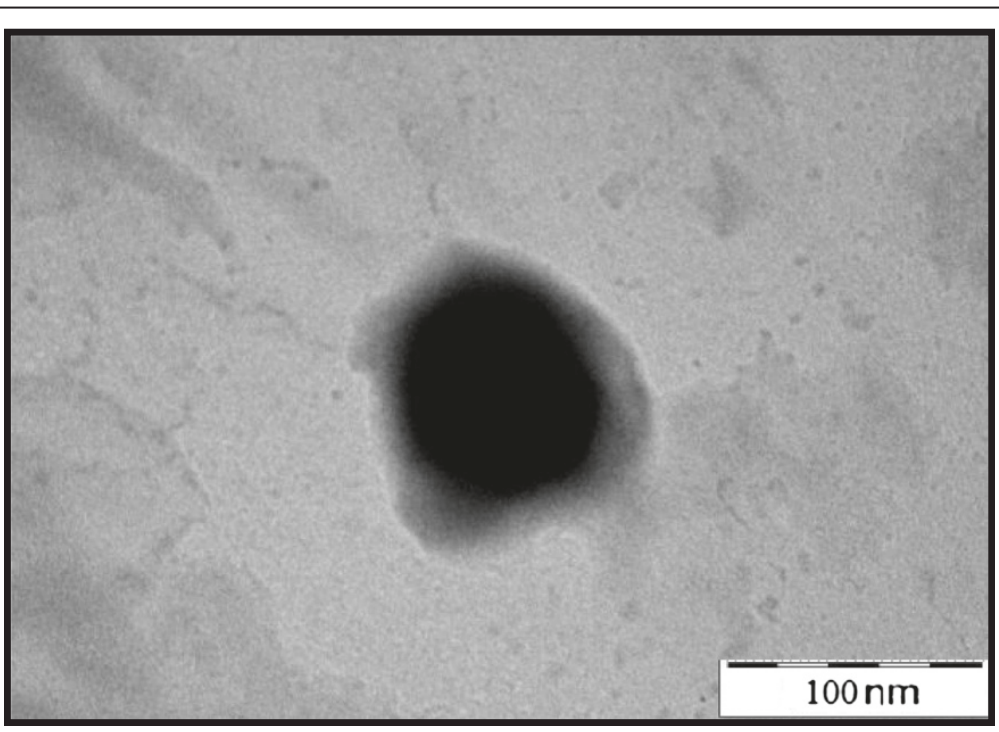

Figure 1 TEM micrograph of OPS nanoparticles. 


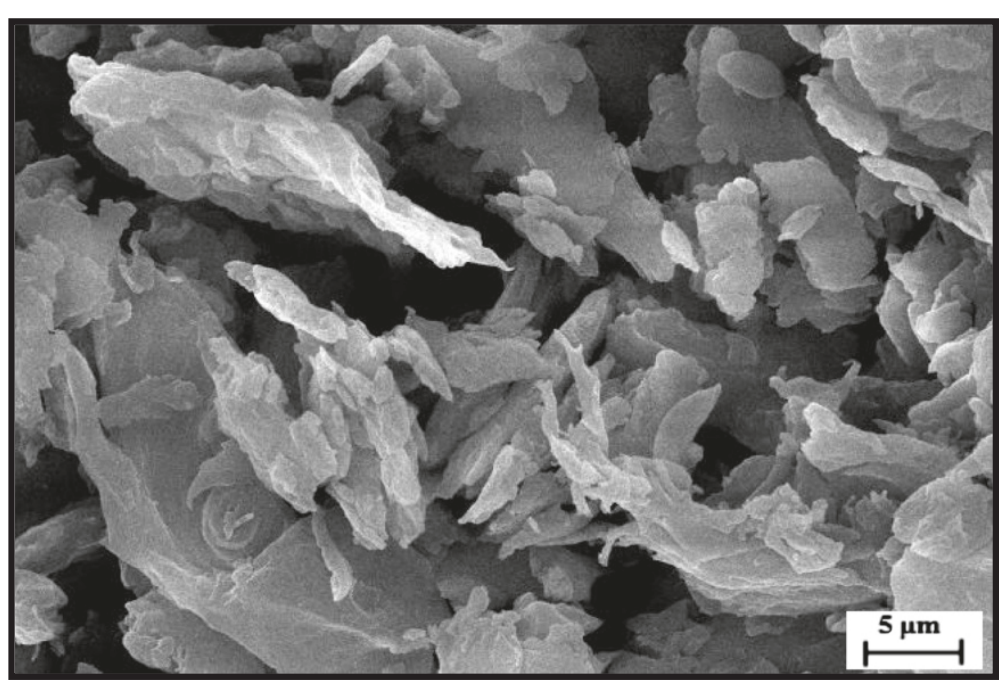

Figure 2 SEM micrograph of OPS nanoparticles (1000× magnification).

decreased the weight loss of PF-NPI OPTL due to weathering. The decline rate of this weight loss increased with the increase of nanoparticles percentage up to $5 \%$. The weight loss also increased with the increase of exposure time. The average weight losses were $36.4 \%$; $31.8 \% ; 31.5 \% ; 23.7 \%$, and $27.5 \%$, respectively for $0,1,3$, 5 , and $10 \%$ PF-NPI OPTL after 12 months of exposure at natural weathering condition. There were statistically significant difference between the nanoparticles concentration of $5 \%$ and other concentration $(0,1,3$, and $10 \%)$, and duration exposure of 6 and 12 months. However, there were no significant differences for $0,1,3$ and $10 \%$ nanoparticles concentrations. On the other hand, the average weight losses of untreated OPTL were very high for both 6 (37.3\%) and 12 (41.1\%) months exposure time. It was found that there was significant difference between treated and untreated samples for any duration of exposure; however, this difference was not significant between different concentrations (C) of nanoparticles impregnation according to Duncan Multiple Range Test (DMRT). The duration of exposure (ET) also affected the weight loss significantly. However, the interaction between C and ET were not significant (Table 3).

Weight loss prevention ratios were higher in PF-NPI compared to the only PF impregnated OPTL. The weight loss prevention ratio (\%) was the highest when there were $5 \%$ nano particle impregnation for both 6 and 12 months of exposure. From this result, it is clear that the rate of weight loss is the function of time. It indicates that weathering occurs due to photodegradation of lignin in the materials, and leaching of those degraded lignin fragments from the exposed

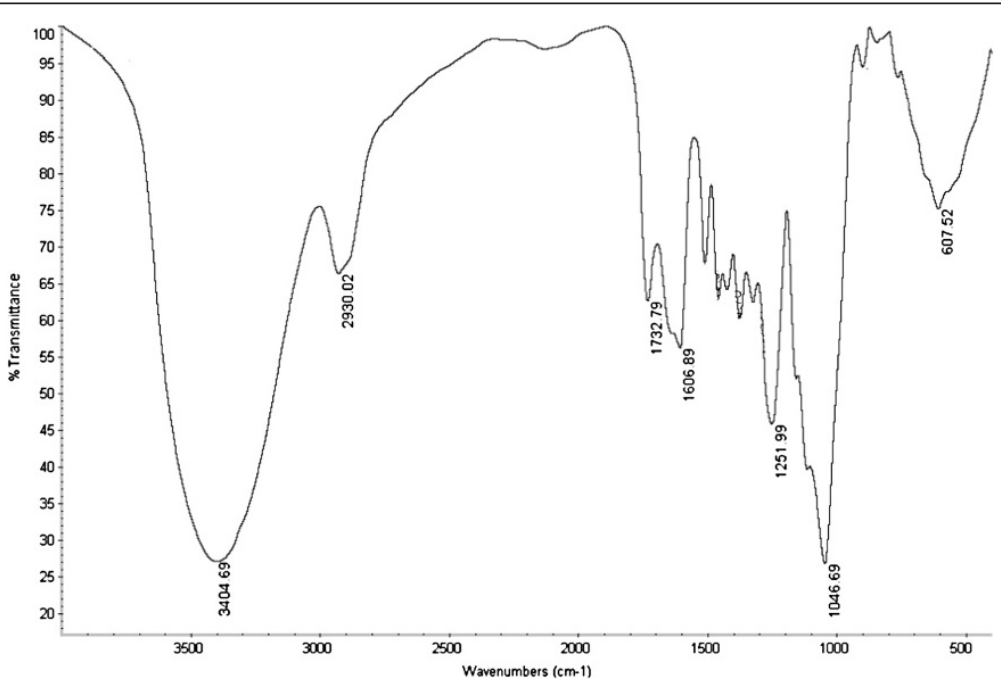

Figure 3 FT-IR spectra of OPS nanoparticles. 
Table 2 Effect of OPS nanoparticles impregnation into OPTL on weight loss and weight loss prevention ratio after 6 and 12 months of weathering

\begin{tabular}{lcccc}
\hline Nanoparticles (\%) & \multicolumn{2}{c}{ Weight loss (\%) } & \multicolumn{2}{c}{ Weight loss prevention ratios (\%) } \\
\cline { 2 - 3 } \cline { 2 - 3 } OPTL & $\mathbf{6}$ months & $\mathbf{1 2}$ months & 6 months & 12 months \\
0 & $37.31(0.89)^{*}$ & $36.37(0.95) \mathrm{Ab}$ & +24.28 & + \\
1 & $28.25(0.79) \mathrm{Aa}$ & $31.84(1.00) \mathrm{Ab}$ & +4.94 & +11.49 \\
3 & $26.84(0.82) \mathrm{Aa}$ & $31.47(0.91) \mathrm{Ab}$ & +16.68 & +12.46 \\
5 & $24.95(0.95) \mathrm{Aa}$ & $25.59(0.95) \mathrm{Bb}$ & +32.99 & +13.47 \\
10 & $18.93(0.86) \mathrm{Ba}$ & $29.51(1.04) \mathrm{Ab}$ & +21.25 & +29.64 \\
\hline
\end{tabular}

Values are means $(n=5) ;$ *Values in parentheses are standard deviation; different upper and lower case letters indicate significant differences at $95 \%$ confidence level.

sample surfaces (Bhat et al. 2010b). The impregnated nanoparticles and PF resins also undergo the leaching process.

As reported earlier, weight loss of the exposed surface of the weathered specimens was normally due to the formation of water soluble products in addition with gaseous and volatile products (Futo 1974; 1976). The exposed samples then attacked by the microbes, which also reduced the weight (Bhat et al. 2010b). However, weathering varies with many factors like species of wood, density, and climatic conditions (amount of irradiation, rain action, wind) (Feist 1990; 1983).

\section{Change of functional groups due to natural weathering}

Figure 4 shows the FT-IR spectra of dried OPTL, PF impregnated and PF-NP impregnated OPTL at 0,6 and 12 months of exposure to the weathering condition. It was found that impregnation of PF or PF-NP caused some significant changes in the FT-IR spectra of the OPTL. The assignments of the characteristic IR absorption peaks in OPTL are listed in Table 4. The overall absorption peak decreased with the increase of exposure duration. A strong absorption peak was observed at $3419 \mathrm{~cm}^{-1}, 3415 \mathrm{~cm}^{-1}$, and $3419 \mathrm{~cm}^{-1}$ for 0,6 , and 12 months exposure, respectively for the dried OPTL (Figure 4a). However, these peaks were are $3412 \mathrm{~cm}^{-1}$, $3414 \mathrm{~cm}^{-1}$ and $3423 \mathrm{~cm}^{-1}$ for $\mathrm{PF}$, and at $3740 \mathrm{~cm}^{-1}$, $3412 \mathrm{~cm}^{-1}$ and $3413 \mathrm{~cm}^{-1}$ for PF-NPI OPTL, respectively for 0,6 , and 12 months exposure. The IR spectrum in the range of $3423-3412 \mathrm{~cm}^{-1}$ represent the stretching vibrations of $\mathrm{O}-\mathrm{H}$ bond in cellulose (Pandey and Pitman
2003). However, the absorption peak appeared at $3740 \mathrm{~cm}^{-1}$ for PF-NPI at 0 month exposure was also assigned to hydrogen bond $(\mathrm{O}-\mathrm{H})$ stretching vibration (Blitz and Augustine 1994). The spectra of 1047$1045 \mathrm{~cm}^{-1}$ represents silicate minerals (Si-O bonds) (Georgokapoulos et al. 2003) which was not found in PF-NPI treated OPTL. The hydroxyl stretching bond of water $\left(3435 \mathrm{~cm}^{-1}\right)$ (Pongjanyakul et al. 2009) was only found in PF-NPI OPTL before the exposure to weathering condition. The peak for aromatic ring $(\mathrm{C}=\mathrm{C}$ in plane) was only found at $1606 \mathrm{~cm}^{-1}$ for PF-NPI OPTL at 6 months exposure. The broad absorption band at around $1120 \mathrm{~cm}^{-1}$ attributes to a stretching vibration of Si-O-Si linkage (Galeener 1979).

After exposure to weathering condition, various chemical reactions took place such as dehydration, hydrolysis, oxidation, decarboxylation, and transglycosylation resulting the changes in FT-IR spectra (Kocaefe et al. 2008). Photo-induced degradation of treated and untreated wood caused the main changes in the absorption intensity as were reported by Temiz et al. (2007). However, the intensity of the changes of these bands was related to the change of functional groups and chemical structure of the samples.

Several peaks in the stretching vibrations of $\mathrm{O}-\mathrm{H}$ bond in cellulose at region $(3419-3412) \mathrm{cm}^{-1}$ in spectrum of samples, which were changed to peak at region (3415$3414 \mathrm{~cm}^{-1}$ ) and 3423-3413 after 6 and 12 months, respectively. These findings of decreased intensity at the peak with increasing exposure time were in consistent with the study carried out by Yildiz et al. (2011). They

Table 3 A summary of the analysis of variance $(p>0.05)$ for concentration of nanoparticles and exposure time

\begin{tabular}{|c|c|c|c|c|c|c|c|c|c|c|c|c|}
\hline \multirow[t]{2}{*}{ Variables } & \multirow[t]{2}{*}{ df } & \multicolumn{11}{|c|}{$p$-value } \\
\hline & & WL & WA & SC & ASE & D & TS & TM & EB & FS & $\mathrm{FM}$ & IS \\
\hline Concentration (C) & 4 & 0.543 & 0.000 & 0.000 & 0.000 & 0.000 & 0.000 & 0.000 & 0.000 & 0.000 & 0.000 & 0.000 \\
\hline Exposure time (ET) & 2 & 0.00 & 0.000 & 0.000 & 0.000 & 0.000 & 0.000 & 0.000 & 0.000 & 0.000 & 0.000 & 0.000 \\
\hline $\mathrm{C} \times \mathrm{ET}$ & 8 & 0.294 & 0.016 & 0.000 & 0.063 & 0.000 & 0.936 & 0.562 & 0.155 & 0.997 & 0.759 & 0.295 \\
\hline
\end{tabular}

WL: weight loss; WA: water absorption; SC: swelling coefficient; ASE: anti-swelling efficiency; D: density; TS: tensile strength; TM: tensile modulus; EB: elongation at break; FS: flexural strength; FM: flexural modulus; IS: impact strength. 
(a)

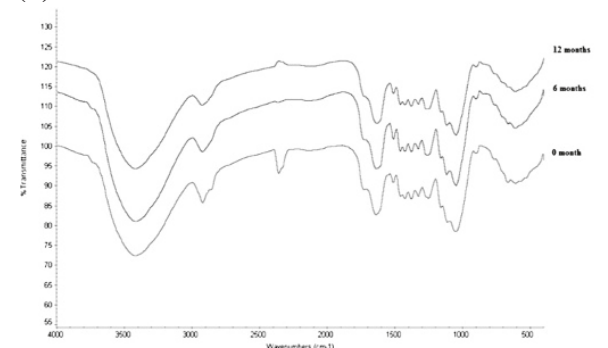

(b)

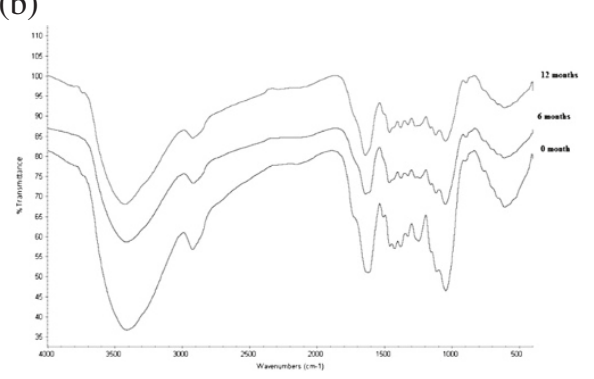

(c)

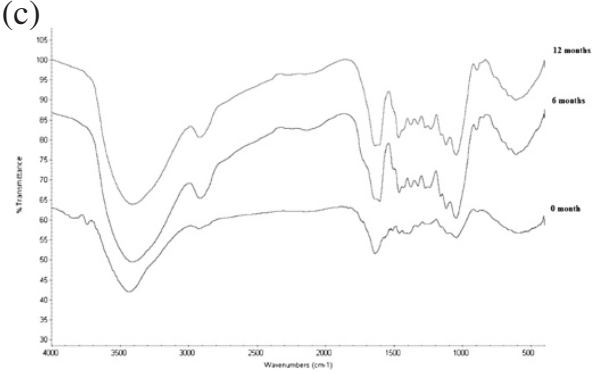

Figure 4 FT-IR spectra of OPTL at different conditions. (a) dried, (b) PF impregnated, and (c) PF-NPI OPTL.

reported that weathering process caused more reduction in the range of 1720 to $1740 \mathrm{~cm}^{-1}(\mathrm{C}=\mathrm{O}$ stretching $)$ than heat treatment at all treatment temperatures and durations, suggesting that there were decreasing photooxidation of wood surface after sunlight irradiation.

The absorption peak changes with the increase of nanoparticles concentration and duration of exposure. The PF-NPI OPTL had chemical changes in lignin and cellulose similar to that of acetylated wood as was studied by Feist et al. (1991). The study suggests that the observed reduction in weathering (weight loss) of PF-NPI OPTL may be a result of polymerization of both resin and nanoparticles. The free radical process may be disrupted during weathering when these components are polymer impregnated function as barrier and the weathering process is then retarded (Feist and Hon 1984).

\section{Change of mechanical properties due to natural weathering}

As expected, mechanical properties (tensile, flexural, and impact strength) of all samples deteriorated due to the weathering effects and it was the highest for 12 months exposure duration. Table 5 shows the change of mechanical properties due to weathering for different duration of exposure. Tensile Strength (TS), Tensile Modulus (TM) and Elongation at Break (EB) of PF-NPI (5\% nano particle) decreased from 4.8 to $11.1 \%, 23.7$ to $43.0 \%$ and 16.4 to $24.5 \%$, respectively when the exposure duration increased from 6 to 12 months. This change was 2.4 to $4.4 \%, 16.0$ to $28.3 \%$ and $8.0-13.3 \%$, respectively for Flexural Strength (FS), Flexural Modulus (FM) and Impact Strength (IS). The change of all these mechanical properties was significantly higher for untreated OPTL samples compared to the treated one. PF resin and the OPS nanoparticles filled the cell lumen to form a rigid cross-linked polymer which improved the strength and stiffness of the OPTL (Nur Izreen et al. 2011). Thus, treated samples had higher mechanical properties compared to the untreated one even after weathering. Nur Izreen et al. (2011) reported similar mechanical properties losses due to natural weathering. The statistical analysis showed that both $\mathrm{C}$ and ET had significant effect on the mechanical properties of OPTL after exposing to weathering condition, however, their interaction had no significant effect on the tested properties (Table 3).

Several researchers have been proved that weathering reduced the mechanical properties (Bhat et al. 2010b; Esteves et al. 2008). They suggested that polymer degradation was mainly caused by chemical bond scission reactions in macro molecules. It was found that long-term exposed of the composites to elevated conditions affected the mechanical properties. Solar irradiance (UV component of the sunlight), relative humidity and temperature are the causal agents of this deterioration of natural fiber of impregnated samples (Lopez et al. 2006). The increase in the mechanical properties due to the chemical modification has been reported by several researchers. Bhat et al. (2010b) found that the flexural properties was attributed to the reaction of hydroxyl groups of cell wall polymers with the anhydrides, converting them into acetyl groups.

Change of physical properties due to natural weathering Similar to mechanical properties, physical properties also changed with the exposure time of PF and PF-NP 
Table 4 Changes of FT-IR spectra due to the exposure to weathering condition at different exposure durations

\begin{tabular}{|c|c|c|c|c|}
\hline \multirow[t]{2}{*}{ Treatment } & \multicolumn{3}{|c|}{ Wave numbers $\left(\mathrm{cm}^{-1}\right)$} & \multirow[t]{2}{*}{ Assignments and Remarks } \\
\hline & 0 month & 6 months & 12 months & \\
\hline \multirow[t]{9}{*}{ Dried OPTL } & 3419 & 3415 & 3419 & stretching vibrations of O-H bond in cellulose (Pandey and Pitman 2003) \\
\hline & 2922 & 2925 & 2925 & $\mathrm{CH}_{2}$ asymetry stretching (Pandey and Pitman 2003) \\
\hline & 2358 & 2360 & - & 2360-2358 ( $C=$ O stretching due to presence of carbondioxide) (Devi and Maji 2012) \\
\hline & 1641 & 1636 & 1639 & - 1641 (amide (N-C=O) (Devi and Maji 2012) \\
\hline & & & & - $1636(C=O, C=C)($ Devi and Maji 2012) \\
\hline & & & & - $1639(C=0, C=C)($ Devi and Maji 2012) \\
\hline & - & - & 1253 & 1253 (Guaiacyl ring structure lignin) (Pandey and Pitman 2003) \\
\hline & 1047 & 1047 & 1046 & 1047-1046 (silicate minerals (Si-O bonds) (Georgokapoulos et al. 2003) \\
\hline & 608 & 608 & 613 & presence of poly hydroxyl groups (Klinkaewnarong and Maensiri 2010) \\
\hline \multirow[t]{11}{*}{ PF impregnated } & 3412 & 3414 & 3423 & stretching vibrations of O-H bond in cellulose (Pandey and Pitman 2003) \\
\hline & 2924 & 2919 & 2923 & $\mathrm{CH}_{2}$ asymetry stretching (Pandey and Pitman 2003) \\
\hline & 1620 & 1640 & 1639 & - 1620 (OH bending) (Devi and Maji 2012) \\
\hline & & & & - 1640 (amide (N-C=O) (Devi and Maji 2012) \\
\hline & & & & - 1639 (OH stretching linked water to cellulose) (Pandey and Pitman 2003) \\
\hline & - & - & 1462 & 1462 (C-H deformation and aromatic ring vibration) (Sun et al. 1999) \\
\hline & 1246 & - & - & destruction of the guaiacyl units (Sun et al. 1999) \\
\hline & 1045 & 1046 & 1045 & - 1045 (silicate minerals (Si-O bonds) (Georgokapoulos et al. 2003) \\
\hline & & & & - 1046 (silicate minerals (Si-O bonds) (Georgokapoulos et al. 2003) \\
\hline & - & 891 & - & - (CH deformation in cellulose) (Pandey and Pitman 2003) \\
\hline & 608 & 610 & 606 & poly hydroxy groups (Klinkaewnarong and Maensiri 2010) \\
\hline \multirow[t]{15}{*}{ PF-NP impregnated } & 3740 & 3412 & 3413 & 3412-3413 stretching vibrations of O-H bond in cellulose) (Pandey and Pitman 2003) \\
\hline & 3435 & - & - & (N-H stretching) (Pongjanyakul et al. 2009) \\
\hline & 2925 & 2914 & 2921 & - 3435 (N-H stretching) (Pongjanyakul et al. 2009) \\
\hline & & & & - 2925-2914 ( $\mathrm{CH}_{2}$ asymetry stretching) (Pandey and Pitman 2003) \\
\hline & 1637 & 1606 & 1640 & - $1637(C=O, C=C)$ (Sun et al. 1999) \\
\hline & & & & - 1606 (aromatic skeleton vibration in lignin) (Sun et al. 1999) \\
\hline & & & & - 1640 (amide (N-C=O) (Devi and Maji 2012) \\
\hline & - & - & 1467 & 1467 (C-H deformations and aromatic ring vibrations) (Sun et al. 1999) \\
\hline & - & 1118 & 1120 & - 1118 (Aromatic skeletal and C-O stretching) (Sun et al. 1999) \\
\hline & & & & - 1120 (stretching vibration of Si-O-Si linkage) (Galeener 1979) \\
\hline & 1045 & 1046 & 1046 & 1046-1045 (silicate minerals (Si-O bonds) (Georgokapoulos et al. 2003) \\
\hline & - & - & 894 & (CH deformation in cellulose) (Pandey and Pitman 2003) \\
\hline & - & 613 & 610 & - 613 (poly hydroxy groups) (Klinkaewnarong and Maensiri 2010) \\
\hline & & & & - 610 (poly hydroxy groups) (Klinkaewnarong and Maensiri 2010) \\
\hline & 589 & - & - & The zbend of $\mathrm{N}_{2} \mathrm{O}$ (Klinkaewnarong and Maensiri 2010) \\
\hline
\end{tabular}

impregnated OPTL. The change of these properties with different exposure time to weathering condition is shown in Table 5. The change of these physical properties was the lowest for PF-NPI followed by PF impregnation and untreated OPTL which indicated that treatment enhanced the properties of OPTL. The density of PF impregnated OPTL decreased 23.8 and $52.4 \%$ for 6 and 12 months of exposure to the weathering condition. The density change was positively correlated with the nanoparticles concentration, however, inversely correlated with the exposure time. The PF-NPI decreased the water absorption (WA) for a concentration of $5 \%$ nanoparticles; however, higher nanoparticles concentration increased the water absorption. This might be because of the lower degree of crystallinity of OPS nanoparticles which leaded to higher water absorption of the sample. The reduced degree of water absorption due to the replacement of the hydroxyl groups with carbon 
Table 5 Effects of OPS nanoparticles impregnation on mechanical and physical properties due to the exposure to weathering condition at different exposure durations

\begin{tabular}{|c|c|c|c|c|c|c|c|c|c|c|c|c|c|c|c|}
\hline \multirow[t]{2}{*}{$\overline{\text { Nanoparticles (\%) }}$} & \multicolumn{3}{|c|}{ Tensile strength (MPa)/month } & \multicolumn{3}{|c|}{ Tensile modulus (GPa)/month } & \multicolumn{3}{|c|}{ Elongation at break $(\%) /$ month } & \multicolumn{3}{|c|}{ Flexural strength $(\mathrm{MPa}) /$ month } & \multicolumn{3}{|c|}{ Flexural modulus (GPa)/month } \\
\hline & 0 & 6 & 12 & 0 & 6 & 12 & 0 & 6 & 12 & 0 & 6 & 12 & 0 & 6 & 12 \\
\hline \multirow[t]{3}{*}{0} & 9.81Aa & $8.22 \mathrm{Ab}$ & $6.70 \mathrm{Ac}$ & $2.67 \mathrm{ABa}$ & 1.89ABEb & $1.02 \mathrm{ABC}$ & $7.83 \mathrm{Aa}$ & $7.15 \mathrm{Ab}$ & $6.40 \mathrm{Ac}$ & 14.46Aab & 13.49Abac & $12.62 \mathrm{Acb}$ & $4.35 \mathrm{Aa}$ & 3.65AEb & 2.95ABCDEC \\
\hline & $(0.14)^{*}$ & $(1 / 05)^{*}$ & $(0.90)^{*}$ & $(0.15)^{*}$ & $(0.27)^{*}$ & $(0.15)^{*}$ & $(0.35)^{*}$ & $(0.30)^{*}$ & $(0.32)^{*}$ & $(0.24)^{*}$ & $(0.90)^{*}$ & $(0.81)^{*}$ & $(0.17)^{*}$ & $(0.33)^{*}$ & $(0.32)^{*}$ \\
\hline & & $-16.21^{* *}$ & $-31.70^{* *}$ & & $-29.21^{* *}$ & $-61.80^{* *}$ & & $-8.68^{* *}$ & $-18.26^{* *}$ & & $-6.71^{* *}$ & $-12.72^{* *}$ & & $-16.09^{* *}$ & $-32.18^{* *}$ \\
\hline \multirow[t]{3}{*}{1} & $12.51 \mathrm{Ba}$ & 11.44Bba & $9.75 \mathrm{BC}$ & 2.85BAa & 1.98BAEb & 1.33BAEC & $7.65 \mathrm{Ba}$ & 7.19BEb & 6.42BEC & 29.35Bab & 28.21BEbac & 27.35BEcb & $4.67 \mathrm{Ba}$ & 3.94BCb & 3.12BACDEC \\
\hline & $(0.27)^{*}$ & $(1.00)^{*}$ & $(1.00)^{*}$ & $(0.17)^{*}$ & $(0.32)^{*}$ & $(0.28)^{*}$ & $(0.37)^{*}$ & $(0.35)^{*}$ & $(0.34)^{*}$ & $(0.91)^{*}$ & $(0.84)^{*}$ & $(0.97)^{*}$ & $(0.18)^{*}$ & $(0.26)^{*}$ & $(0.29)^{*}$ \\
\hline & & $-8.55^{* *}$ & $-22.06^{* *}$ & & $-30.53^{* *}$ & $-53.33^{* *}$ & & $-6.01^{* *}$ & $-16.08^{* *}$ & & $-3.88^{* *}$ & $-6.81^{* *}$ & & $-15.63^{* *}$ & $-33.19^{* *}$ \\
\hline \multirow[t]{3}{*}{3} & $17.17 \mathrm{Ca}$ & 15.57CEb & 14.25CEC & 3.25CEa & $2.62 \mathrm{CDb}$ & $2.10 C D C$ & $7.18 \mathrm{Ca}$ & 6.32CDba & $5.38 \mathrm{CDC}$ & $33.51 \mathrm{Ca}$ & $32.72 \mathrm{Cba}$ & $31.68 \mathrm{Cc}$ & $4.81 \mathrm{Ca}$ & $3.89 \mathrm{CBb}$ & 3.20CABDEC \\
\hline & $(0.11)^{*}$ & $(0.94)^{*}$ & $(0.96)^{*}$ & $(0.18)^{*}$ & $(0.36)^{*}$ & $(0.32)^{*}$ & $(0.38)^{*}$ & $(0.30)^{*}$ & $(0.30)^{*}$ & $(0.35)^{*}$ & $(0.68)^{*}$ & $(0.67)^{*}$ & $(0.19)^{*}$ & $(0.29)^{*}$ & $(0.29)^{*}$ \\
\hline & & $-9.32^{* *}$ & $-17.01^{* *}$ & & $-19.38^{* *}$ & $-35.38^{* *}$ & & $-11.98^{* *}$ & $-25.07^{* *}$ & & $-2.36^{* *}$ & $-10.78^{* *}$ & & $-19.13^{* *}$ & $-33.47^{* *}$ \\
\hline \multirow[t]{3}{*}{5} & $19.64 \mathrm{Da}$ & 18.69Dba & $17.38 \mathrm{Dc}$ & 3.51 Da & $2.68 \mathrm{DCb}$ & $2.00 \mathrm{DCC}$ & $6.42 \mathrm{Da}$ & $5.37 \mathrm{DCb}$ & $4.85 \mathrm{DCC}$ & $38.55 \mathrm{Da}$ & $37.62 \mathrm{Dbc}$ & $36.84 \mathrm{Dcb}$ & $4.95 \mathrm{Da}$ & $4.16 \mathrm{Db}$ & 3.55DACDEC \\
\hline & $(0.09)^{*}$ & $(0.95)^{*}$ & $(0.93)^{*}$ & $(0.20)^{*}$ & $(0.32)^{*}$ & $(0.32)^{*}$ & $(0.39)^{*}$ & $(0.31)^{*}$ & $(0.33)^{*}$ & $(0.23)^{*}$ & $(0.86)^{*}$ & $(0.67)^{*}$ & $(0.22)^{*}$ & $(0.30)^{*}$ & $(0.36)^{*}$ \\
\hline & & $-4.84^{* *}$ & $-11.07^{* *}$ & & $-23.65^{* *}$ & $-43.02^{* *}$ & & $-16.35^{* *}$ & $-24.45^{* *}$ & & $-2.41^{* *}$ & $-4.43^{* *}$ & & $-15.96^{* *}$ & $-28.28^{* *}$ \\
\hline \multirow[t]{3}{*}{10} & 16.72Еa & 15.13EDb & 13.50ECc & 3.12ECa & 2.12EABb & 1.57EAc & 7.35Ea & 6.18EBb & $5.28 \mathrm{EBC}$ & 30.12Ea & 28.76EBbc & 28.02EBcb & $4.57 \mathrm{Ea}$ & 3.85EAb & 3.19EABCDC \\
\hline & $(0.40)^{*}$ & $(0.83)^{*}$ & $(0.95)^{*}$ & $(0.32)^{*}$ & $(0.32)^{*}$ & $(0.30)$ & $(0.33)^{*}$ & $(0.32)^{*}$ & $(0.34)^{*}$ & $(0.35)^{*}$ & $(0.80)^{*}$ & $(0.80)^{*}$ & $(0.27)^{*}$ & $(0.30)^{*}$ & $(0.36)^{*}$ \\
\hline & & $-9.51^{* *}$ & $-19.26^{* *}$ & & $-32.05^{* *}$ & $-49.68^{* *}$ & & $-15.92^{* *}$ & $-28.16^{* *}$ & & $-4.52^{* *}$ & $-6.97^{* *}$ & & $-15.75^{* *}$ & $-30.20^{* *}$ \\
\hline \multirow[t]{2}{*}{ Nanoparticles (\%) } & \multicolumn{3}{|c|}{ Impact strength $\left(\mathrm{k} . \mathrm{J} / \mathrm{m}^{2}\right) /$ month } & \multicolumn{3}{|c|}{ Density $\left(\mathrm{g} / \mathrm{cm}^{3}\right) /$ month } & \multicolumn{3}{|c|}{ Water absorption (\%)/month } & \multicolumn{3}{|c|}{ Swelling coefficient (\%)/month } & \multicolumn{3}{|c|}{ Antiswelling efficiency (\%)/month } \\
\hline & 0 & 6 & 12 & 0 & 6 & 12 & 0 & 6 & 12 & 0 & 6 & 12 & 0 & 6 & 12 \\
\hline \multirow[t]{3}{*}{0} & $6.90 \mathrm{Aa}$ & $5.76 \mathrm{Ab}$ & $4.55 \mathrm{Ac}$ & $0.42 \mathrm{Aa}$ & $0.32 \mathrm{Ab}$ & $0.20 \mathrm{Ac}$ & 37.98Aa & 45.69Aba & $50.53 \mathrm{Ac}$ & $6.36 \mathrm{Aa}$ & $14.65 \mathrm{Ab}$ & $20.04 \mathrm{ACC}$ & $47.20 \mathrm{Aa}$ & $43.27 \mathrm{Ab}$ & $40.04 \mathrm{Ac}$ \\
\hline & $(0.28)^{*}$ & $(0.40)^{*}$ & $(0.41)^{*}$ & $(0.01)^{*}$ & $(0.03)^{*}$ & $(0.03)^{*}$ & $(0.93)^{*}$ & $(1.95)^{*}$ & $(1.52)^{*}$ & $(0.13)^{*}$ & $(1.94)^{*}$ & $(1.81)^{*}$ & $(1.32)^{*}$ & $(1.82)^{*}$ & $(1.84)^{*}$ \\
\hline & & $-16.52^{* *}$ & $-34.06^{* *}$ & & $-23.81^{* *}$ & $-52.38^{* *}$ & & $+16.87^{* *}$ & $+24.84^{* *}$ & & $+54.59^{* *}$ & $+68.26^{* *}$ & & $-8.33^{* *}$ & $-15.17^{* *}$ \\
\hline \multirow[t]{3}{*}{1} & 10.92BEa & 10.00BEb & 9.39BEC & $0.66 \mathrm{Ba}$ & $0.52 \mathrm{Bb}$ & $0.35 B C$ & $27.79 \mathrm{Ba}$ & 37.48Bb & 44.77BC & $5.75 \mathrm{Ba}$ & 11.10BCEb & $14.35 \mathrm{BC}$ & 56.23Ba & $51.37 \mathrm{Bb}$ & $46.35 B C$ \\
\hline & $(0.24)^{*}$ & $(0.41)^{*}$ & $(0.44)^{*}$ & $(0.01)^{*}$ & $(0.03)^{*}$ & $(0.03)^{*}$ & $(0.91)^{*}$ & $(1.51)^{*}$ & $(1.64)^{*}$ & $(0.17)^{*}$ & $(1.78)^{*}$ & $(2.08)^{*}$ & $(1.31)^{*}$ & $(1.75)$ & $(1.99)^{*}$ \\
\hline & & $-16.52^{* *}$ & $-34.06^{* *}$ & & $-21.21^{* *}$ & $-46.97^{* *}$ & & $+25.85^{* *}$ & $+37.93^{* *}$ & & $+48.20^{* *}$ & $+59.19^{* *}$ & & $-8.64^{* *}$ & $-17.57^{* *}$ \\
\hline \multirow[t]{3}{*}{3} & $13.13 \mathrm{Ca}$ & $12.23 \mathrm{Cb}$ & $11.34 \mathrm{Cc}$ & $0.70 \mathrm{Ca}$ & $0.53 \mathrm{CBb}$ & $0.41 \mathrm{CEC}$ & 26.34CAa & $34.61 \mathrm{Cb}$ & $38.86 \mathrm{Cc}$ & $4.81 \mathrm{Ca}$ & 9.88CAEb & 13.24CAEC & $60.82 \mathrm{Ca}$ & $57.39 \mathrm{Cb}$ & $57.39 \mathrm{Cc}$ \\
\hline & $(0.25)^{*}$ & $(0.33)^{*}$ & $(0.36)^{*}$ & $(0.01)^{*}$ & $(0.03)^{*}$ & $(0.03)^{*}$ & $(0.82)^{*}$ & $(1.67)^{*}$ & $(1.55)^{*}$ & $(0.11)^{*}$ & $(1.93)^{*}$ & $(1.89)^{*}$ & $(1.44)^{*}$ & $(1.89)^{*}$ & $(1.89)^{*}$ \\
\hline & & $-6.85^{* *}$ & $-13.63^{* *}$ & & $-24.29^{* *}$ & $-41.43^{* *}$ & & $+23.89^{* *}$ & $+32.22^{* *}$ & & $+51.31^{* *}$ & $+63.67^{* *}$ & & $-5.64^{* *}$ & $-13.76^{* *}$ \\
\hline \multirow[t]{3}{*}{5} & $15.85 \mathrm{Da}$ & $14.58 \mathrm{Db}$ & $13.75 \mathrm{DC}$ & $0.89 \mathrm{Da}$ & $0.72 \mathrm{Dba}$ & $0.57 \mathrm{Dc}$ & $24.15 \mathrm{Da}$ & $32.58 \mathrm{DCb}$ & 40.61DCC & $3.66 \mathrm{Da}$ & $6.91 \mathrm{Dbc}$ & 8.67 Dcb & $69.57 \mathrm{Da}$ & $62.48 \mathrm{Db}$ & 57.97Dc \\
\hline & $(0.25)^{*}$ & $(0.42)^{*}$ & $(0.40)^{*}$ & $(0.02)^{*}$ & $(0.03)^{*}$ & $(0.04)^{*}$ & $(0.91)^{*}$ & $(1.65)^{*}$ & $(1.70)^{*}$ & $(0.10)^{*}$ & $(1.69)^{*}$ & $(1.85)^{*}$ & $(0.84)^{*}$ & $(1.72)^{*}$ & $(1.77)^{*}$ \\
\hline & & $-8.01 * *$ & $-13.25^{* *}$ & & $-19.10^{* *}$ & $-35.95^{* *}$ & & $+25.87^{* *}$ & $+40.53^{* *}$ & & $+47.03^{* *}$ & $+57.78^{* *}$ & & $-10.19^{* *}$ & $-16.67^{* *}$ \\
\hline \multirow[t]{3}{*}{10} & 11.00EBa & 10.17EBb & $9.25 \mathrm{EBC}$ & $0.68 \mathrm{EAa}$ & $0.49 \mathrm{EBb}$ & 0.37 EACc & 27.20EBa & $37.58 \mathrm{EBb}$ & 43.55EBC & $6.88 \mathrm{Ea}$ & 9.37EACbc & 11.40ECcb & 43.14Еа & 38.43Eb & $31.11 \mathrm{EC}$ \\
\hline & $(0.21)^{*}$ & $(0.40)^{*}$ & $(0.38)^{*}$ & $(0.01)^{*}$ & $(0.04)^{*}$ & $(0.04)^{*}$ & $(0.93)^{*}$ & $(1.85)^{*}$ & (1.93) & $(0.12)^{*}$ & $(1.93)^{*}$ & $(1.85)^{*}$ & $(1.44)^{*}$ & $(1.95)^{*}$ & $(1.99)^{*}$ \\
\hline & & $-7.54^{* *}$ & $-15.91^{* *}$ & & $-27.94^{* *}$ & $-45.59^{* *}$ & & $+27.82^{* *}$ & $+37.54^{* *}$ & & $+26.57^{* *}$ & $+39.65^{* *}$ & & $-10.92^{* *}$ & $-27.88^{* *}$ \\
\hline
\end{tabular}


atoms in the PF chains has also been reported by several researchers (Lopez et al. 2006; Abdul Khalil et al. 2010b). Abdul Khalil et al. (2010b) found an interesting result that the highest water absorption because of the presence of more hydroxyl groups in the parenchyma tissue that enabled more hydrogen bonding formation. The swelling coefficient (SC) increased with the exposure time, however, decreased with the increase of nanoparticles concentration up to $5 \%$. While, the antiswelling effeciency (ASE) decreased with the increase of exposure time. The ASE increases linear with increasing concentration nanoparticles at each exposure time. Accordingly, it can be states that PF-impregnated at various concentration nanoparticles and periods may prevent the rate of swelling resulting from decay. The PF-impregnation with $5 \%$ nanoparticles exhibited the lowest ASE change than PF-impregnation with $0,1,3$ and $10 \%$ nanoparticles. The only PF-impregnation exhibited the highest ASE change. Thus, nanoparticles can be widely used to treat the PF-impregnated OPT for increasing the dimensional stability.

Based on these results, the PF resin and nanoparticles in OPTL reduced the porosity and minimized the physical properties change of OPTL resulting from weathering. Moreover, the formation of wall polymers inside the cell wall enhances the physical properties of the OPT (Abdul Khalil et al. 2010b). Statistical analysis indicated that concentration of nano particles as well as exposure time significantly affected the studied physical properties. The interaction of $\mathrm{C}$ and ET had significant effect on density, while no significant effect on WA and ASE (Table 3).

\section{Change of morphological properties due to natural weathering}

The OPT fibres showed great variability in size and shape i.e., both thick and thin cell wall as well as small and large lumina (Figure 5a). Reaction of OPTL due to natural weathering had significant effects on the changes
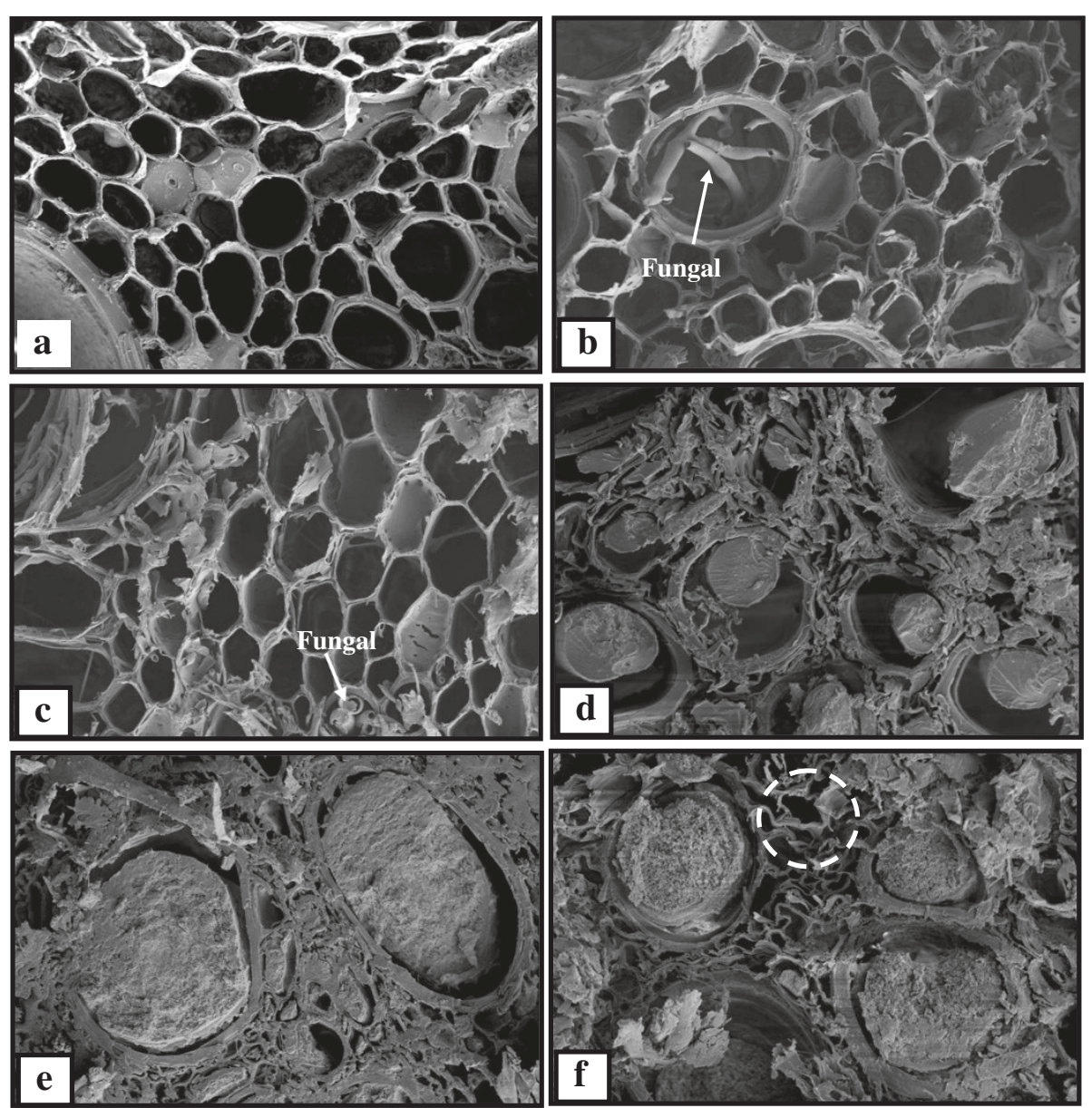

Figure 5 SEM micrographs of OPTL at different weathering conditions. (a) dried OPTL before weathering, (b) dried OPTL after 6 months weathering, (c) dried OPTL after 12 months weathering, (d) PF-impregnated OPTL before weathering, (e) PF-impregnated OPTL after 6 months weathering, and (f) PF-impregnated OPTL after 12 months weathering (500x magnification). 
of morphology. According to Feist and Hon (1984), absorption of UV light by lignin and photolysis and fragmentation of lignin resulting in the formation of aromatic and other radicals. These free radicals may then cause further degradation of lignin and photooxidation of cellulose and hemicelluloses. The phenomena can be well understood by comparing the SEM micrographs of OPTL cross-section before and after weathering (Figure 5a-5c).

Degradation of OPTL surfaces started at relatively low irradiation intensities having an fungi attack on the middle lamella whereas, higher intensities degraded the secondary cell walls (Fengel and Wegener 1989). The control sample showed loss of middle lamella, distortion of cell lumen and delamination of the cell wall after 6 months of exposure to weathering condition (Figure 5b). The OPTL cell wall was weathered and cell lumen became bigger than those of unweathered cell lumen which suggested the erosion of cell wall. Middle lamella appeared to be completely eliminated at the surface of OPTL after weathering with the presence of fungi in cell lumen of fiber. Similar findings were reported by Bhat et al. (2010b) where middle lamella showed holes, cell lumen were distorted and cell wall were degraded for Acacia mangium wood after 1 year of weathering.

On the other hand, distortion and erosion of fiber became more pronounced in the OPTL controls after 12 months of weathering (Figure $5 \mathrm{c}$ ) particularly in the middle lamella and cell lumen. As mention earlier, fungi were found in the cell lumen after 12 months of weathering. Nevertheless, the middle lamella could still be clearly discerned in cell lumen of fiber after 6 months of weathering.

The changes of morphological properties of PF-NPI without nanoparticles after natural weathering are shown in Figure 5d-5f. The sample showed that the middle lamella could still be clearly discerned in these samples after 6 months of weathering (Figure 5e). Some defibrillation in the middle lamella and delamination in the cell wall was apparent in samples after 12 months of weathering (Figure 5f), but overall the changes were less pronounced than in OPTL impregnated samples. The effects of PF-impregnation could retard the formation of aromatic (lignin) radicals that initiate photo-oxidation. Alternatively, it is possible that resin matrix in OPTL scavenged free radicals preventing them from attacking lignin and cellulose. Such a suggestion is consistent with the observations by Nur Izreen et al. (2011) that benzoyl groups in wood obstruct free radicals and photostabilise polymers.

SEM micrograph suggested that the impregnated lumber with nanoparticles reduced the rate of weathering as removal of resin and nanoparticles from OPTL was needed first during weathering. Less weight losses of samples were also occurred due to this factor (Evans et al. 1996). Accordingly, the ability of PF impregnation with nanoparticles to protect lignin from photodegradation might explain why weight losses of impregnated OPTL during natural weathering were

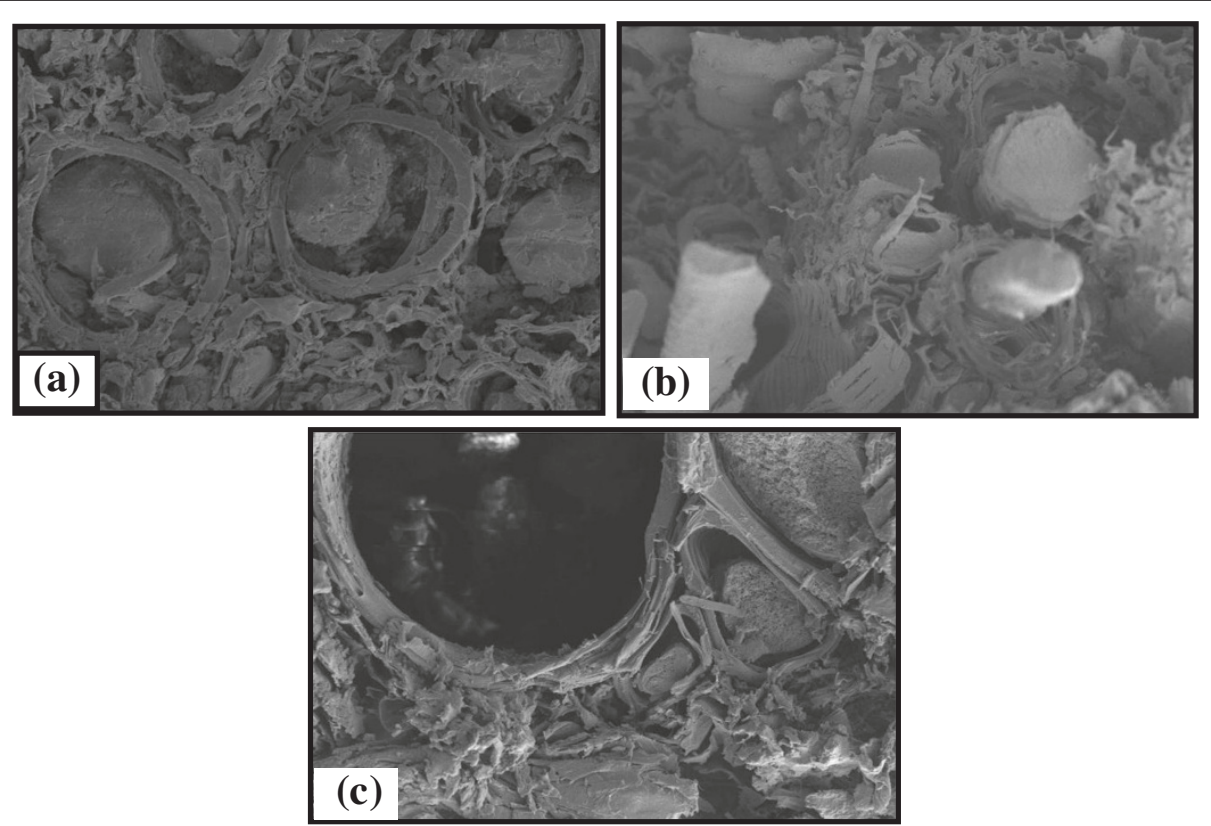

Figure 6 SEM micrograph of OPTL at different weathering durations. (a) PF-NPI before weathering, (b) PF-NPI after 6 months weathering, and (c) PF-NPI after 12 months weathering (500x magnification). 
significantly lower than those of OPTL controls. Previous studies of the weathering of benzoylation of wood showed that benzoylation treatment reduced the formation of free radicals in wood when exposed to UV light, possibly because the benzoyl groups in wood absorbed UV light or scavenged free radicals (Esteves et al. 2008). The effects of water on OPTL weathering was also recognized as one of the principle causes of weathering by changing the dimension resulting cracks and checks formation and undergo degradation (Lopez et al. 2006). However, PF-NPI reduced the water uptake by OPTL during weathering and thus, reduced the degradation. Changes in morphology of PF-NPI specimens were also apparent after 6 months of weathering (Figure 6b). Degradation of the matrix occurred and splits developed in vessel cell (Figure 6b) after 6 months of weathering. After 1 year of exposure to the weathering condition, the matrix structure of PF-NPI specimens was fragile (Figure 6c) with further degradation of the cell walls and opened the cell lumens.

\section{Conclusions}

Oil palm trunk lumber was successfully prepared by impregnation of phenol formaldehyde with OPS nanoparticles by vacuum-pressure method. The OPS nanoparticles appear to increase the quality of OPTL when it is exposed to natural weathering. Among all the PF-NPI OPTL, the addition of $5 \%$ nanoparticles exhibited superior physical and mechanical properties after 12 months of natural weathering. Degradation of the polymer matrix occurred for all PF-NPI during natural weathering, however, no significant differences were observed for the variation of concentrations of nanoparticles. Thus, matrix degradation was independent from the concentration of nanoparticles, however, dependent on the weathering duration. Thus, the impregnation of PF and OPS nanoparticles were effective in retarding the degradation of OPTL against the natural weathering.

\section{Competing interests}

The authors declare that they have no competing interests.

\section{Authors' contributions}

MN Islam, R Dungani, MS Alwani and WOW Nadirah carried out the field study. MN Islam, HPS Abdul Khalil and HM Fizree drafted the manuscript. I also declare that all authors read and approved the final manuscript.

\section{Acknowledgements}

The author would like to thank Universiti Sains Malaysia (USM), Penang, Malaysia, for providing Research Grant no. RU-1001/PTEKIND/811195, and Ministry of Education, Malaysia for providing research grant \# FRGS-203/PTEKIND/6711325. The author would also like to thank Prof. Pingkan Aditiawati, School of Life Sciences and Technology, Institut Teknologi Bandung, West Java-Indonesia and Prof. Y. S. Hadi, Department of Forest Product, Faculty of Forestry, Bogor Agricultural University, West Java, Indonesia, for providing the necessary facilities for preparing the part of the research during the sabbatical leave for the period of December 1, 2011 to August 31, 2012.
}

\section{Author details}

${ }^{1}$ School of Industrial Technology, Universiti Sains Malaysia, 11800 Penang, Malaysia. ${ }^{2}$ School of Life Science, Khulna University, Khulna 9208 Bangladesh. ${ }^{3}$ School of Life Sciences and Technology, Institut Teknologi Bandung,

Gedung Labtex XI, Jalan Ganesha 10, Bandung 40132, West Java, Indonesia.

Received: 1 October 2013 Accepted: 30 October 2013

Published: 6 November 2013

\section{References}

Abdul Khalil HPS, Bhat AH, Jawaid M, Amouzgar P, Ridzuan R, Said MR (2010a) Agro-wastes: mechanical and physical properties of resin impregnated oil palm trunk core lumber. Polym Compos 31(4):638-644

Abdul Khalil HPS, Nurul Fazita MR, Bhat AH, Nik Fuad NA (2010b) Development and material properties of new hybrid plywood from oil palm biomass. Mater Des 31(1):417-424

Abdul Khalil HPS, Amouzgor P, Jawaid M, Hassan A, Ahmad F, Hadiyane A, Dungani R (2012) New approach to oil palm trunk core lumber material properties enhancement via resin impregnation. Biobased Mater Bioenergy 6(3):299-308

Afrouzi YM, Omidvar A, Marzbani P (2013) Effect of artificial weathering on the wood impregnated with Nano-Zinc Oxide. W Appl Sci J 22(9):1200-1203

Arami-Niya A, Wan Daud WMA, Mjalli FS (2010) Using granular activated carbon prepared from oil palm shell by $\mathrm{ZnCl} 2$ and physical activation for methane adsorption. J Anal Appl Pyrol 89(2):197-203

Astimar AA, Mohamad H, Anis M (2002) Preparation of cellulose from oil palm empty fruit bunches via ethanol digestion: effect of acid and alkali catalysts. Oil Palm Res 14(1):9-14

Bhat IUH, Abdullah CK, Abdul Khalil HPS, Hakimi Ibrahim M, Nurul Fazita MR (2010a) Properties enhancement of resin impregnated agro waste: oil palm trunk lumber. Reinf Plast Compos 29(22):3301-3308

Bhat IUH, Abdul Khalil HPS, Khairul BA, Bakare IO, Issam AM (2010b) Effect of weathering on physical, mechanical and morphological properties of chemically modified wood materials. Mater Des 31(9):4363-4368

Blitz JP, Augustine SM (1994) Characterization of heterogeneous catalysts by FT- IR diffuse reflectance spectroscopy. Spectroscopy 9(8):28-34

Colom X, Carrillo F, Nogués F, Garriga P (2003) Structural analysis of photodegraded wood by means of FTIR spectroscopy. Polym Degrad Stab 80(3):543-549

Dagwa IM, Builders PF, Achebo J (2012) Characterization of palm kernel shell powder for use in polymer matrix composites. Int J Mech Mechatronic Eng 12(4):88-93

Devi RR, Maji TK (2012) Chemical modification of simul wood with styreneacrylonitrile copolymer and organically modified nanoclay. Wood Sci Technol 46(1-3):299-315

Esteves BM, Domingos IJ, Pereira HM (2008) Pine wood modification by heat treatment in air. BioResources 3(1):142-154

Evans PD, Thay PD, Schmalzl KJ (1996) Degradation of wood surfaces during natural weathering. Effects on lignin and cellulose and on the adhesion of acrylic latex primers. Wood Sci Technol 30(6):411-422

Feist WC (1983) Finishing wood for exterior use. In: Carter RM (ed) Proceedings 87318 - Finishing Eastern Hardwoods. Forest Products Research Society Co. Kendall/Hunt Publishing Dubuque, lowa

Feist WC (1990) Outdoor wood weathering and protection. In: Rowell RM (ed) Archeological Wood - Properties, Chemistry and Preservation. Advances in Chemistry Series 225. Springer, Berlin, pp 263-298

Feist WC, Hon DNS (1984) Chemistry of weathering and protection. In: Rowell RM (ed) The chemistry of solid wood. Advances in Chemistry Series 207. Springer, pp 401-451

Feist WC, Rowell RM, Ellis WD (1991) Moisture sorption and accelerated weathering of acetylated and methacrylated aspen. Wood Fiber Sci 23(1):128-136

Fengel D, Wegener G (1989) Wood: Chemistry, Ultrastructure, Reactions. Walter de Gruyter, Berlin, p 613

Firoozian P, Bhat IUH, Abdul Khalil HPS, Md Noor A, Hazizan MA, Bhat AH (2011) High surface area activated carbon prepared from agricultural biomass: Empty fruit bunch (EFB), bamboo stem and coconut shells by chemical activation with H3PO4. Mater Technol 26(5):222-228

Futo LP (1974) Der hotochemische abbau des holzes als präparations-und analysenmethode. Holz Roh-Werkst 32(1):303-311 
Futo LP (1976) Effects of temperature on the photochemical degradation of wood. I. experimental presentation. Holz Roh-Werkst 34(1):31-36

Galeener FL (1979) Band limits and the vibrational spectra of tetrahedral glasses. Phys Rev B 19:4292-4297

Geburtig A, Wachtendorf V (2010) Determination of the spectral sensitivity and temperature dependence of polypropylene crack formation caused by UV-irradiation. Polym Degrad Stabil 95(10):2118-2123

Georgokapoulos A, lordanidis A, Kapina V (2003) Study of low rank greek coals using FTIR spectroscopy. Energy Sources 25(10):995-1005

Gobakken LR, Lebow PK (2010) Modelling mould growth on coated modified and unmodified wood substrates exposed outdoors. Wood Sci Technol 44(2):315-333

Hon DN-S (2001) Weathering and photochemistry of wood. In: Hon DN-S, Shiraishi N (ed) Wood and cellulose chemistry. Marcel Dekker, New York, pp 512-546

Klinkaewnarong J, Maensiri S (2010) Nanocrystalline Hydroxyapatite powders by a polymerized complex method. Chiang Mai J Sci 37(2):243-251

Kocaefe D, Poncsak S, Boluk Y (2008) Effect of thermal treatment on the chemical composition and mechanical properties of birch and aspen. BioResources 3(2):517-537

Lei H, Xu T, Gao C (2010) Characterization of the dispersion of tetrapod-like nano-ZnO whiskers in acrylic resin and properties of the nano-composite coating system. Coat Technol Res 7(1):91-97

Lopez JL, Sain M, Cooper P (2006) Performance of natural-fiber-plastic composites under stress for outdoor applications: Effect of moisture, temperature, and ultraviolet light exposure. Appl Polym Sci 99(5):2570-2577

Lua AC, Guo J (2001) Microporous oil palm shell activated carbon prepared by physical activation for gas-phase adsorption. Lagmuir 17(22):7112-7117

Macleod IT, Scully AD, Ghiggino KP, Ritchie PJA, Paravagna MB, Leary B (1995) Photodegradation at the wood-clearcoat interface. Wood Sci Technol 29(3):183-189

Ndiaye D, Fanton E, Morlat-Therias S, Vidal L, Tidjani A, Gardette JL (2008) Durability of wood polymer composites: Part 1. Influence of wood on the photochemical properties. Compos Sci Technol 68(13):2779-2784

Nur Izreen FA, Zaidon A, Rabia'tol Adawiah MA, Bakar ES, Paridah MT, Mohd Hamami S, Anwar UMK (2011) Enhancing the properties of low density hardwood Dyera costulata through impregnation with phenolic resin admixed with formaldehyde scavenger. Appl Sci 11(20):3474-3484

Pandey KK, Pitman AJ (2003) FTIR studies of the changes in wood following decay by brown-rot and white-rot fungi. Int Biodeter Biodegr 52:151-160

Paul K, Satphaty SK, Manna I, Chakraborty KK, Nando GB (2007) Preparation and characterization of nano structured materials from fly ash: a waste from thermal power stations by high energy ball milling. Nano Res Lett 2(8):397-404

Pongjanyakul T, Khunawattanakul W, Puttipipatlehachorn S (2009) Physicochemical characterizations and release studies of nicotinemagnesium aluminum silicate complexes. Appl Clay Sci 44(3\&4):242-250

Robert P, Marquis M, Barron C, Gullon F, Saunier L (2005) FT-IR investigation of cell wall polysaccharides from cereal grains. arabinoxylan infrared assignment. Agri Food Chem 53(18):7014-7018

Ryu JY, Takahashi M, Imamura Y, Sato T (1991) Biological resistance of phenolresin treated wood. Mokuzai Gakkaishi 37(9):852-858

Stamm AJ, Seborg RM (1939) Resin-treated plywood. Ind Eng Chem 31(7):787-926

Sun R, Fang JM, Tomkinson J, Bolton J (1999) Physicochemical and structural characterization of alkali soluble lignins from oil palm trunk and empty fruit-bunch fibers. J Agric Food Chem 47(7):2930-2936

Temiz A, Terziev N, Eikenes M, Hafren J (2007) Effect of accelerated weathering on surface chemistry of modified wood. Appl Surf Sci 253:5355-5362

Wetzel DL, Eilert AJ, Pietrzak LN, Miler SS, Sweat JA (1998) Ultraspatially-resolved synchrotron infrared microspectroscopy of plant tissue in situ. Cell Mol Biol 44(1):145-167

Yildiz S, Yildiz UC, Tomak ED (2011) The effects of natural weathering on the properties of heat-treated alder wood. BioResources 6(3):2504-2521

Zou P, Xiong H, Tang S (2008) Effect of nano-SiO2 on the performance of starch/ polyvinyl alcohol blend films. Carbohyd Polym 73:378-383

\section{doi:10.1186/2193-1801-2-592}

Cite this article as: Islam et al.: Natural weathering studies of oil palm trunk lumber (OPTL) green polymer composites enhanced with oil palm shell (OPS) nanoparticles. SpringerPlus 2013 2:592.

\section{Submit your manuscript to a SpringerOpen ${ }^{\circ}$ journal and benefit from:}

- Convenient online submission

- Rigorous peer review

- Immediate publication on acceptance

Open access: articles freely available online

- High visibility within the field

- Retaining the copyright to your article

Submit your next manuscript at $>$ springeropen.com 